\title{
UEFA: A Successful Pan-European Organization during the Cold War
}

\author{
By Ana Bela Nunes ${ }^{*}$ \& Nuno Valério ${ }^{ \pm}$
}

\begin{abstract}
The purpose of this paper is to analyse the formation of the Union Européenne de Football / European Football Association (UEFA) in the mid-1950s and its evolution during the period of the cold war. Post-World War II Europe was characterized for its division into two zones from an economic and political point of view. Countries from the two zones met in international organizations at the world level and created separate specifically European organizations for cooperation in several economic, political and cultural fields. However, there was an almost complete absence of specifically pan-European organizations bringing together countries from the two zones. The only significant exception was UEFA, which, from the mid-1950s onwards, succeeded in organizing regular football competitions between national and club teams from the whole continent without any significant problems, regardless of the different economic and political systems. This paper will discuss the reasons for such a remarkable achievement.
\end{abstract}

Keywords: UEFA, Europe, cold war, economic and political systems, cooperation

\section{Introduction}

Post-World War II Europe was characterized for its division into two zones from an economic and political point of view. On one side were countries with market economies and democratic or right-wing authoritarian political regimes. On the other side were countries with centrally planned economies and communist political regimes. From the economic point of view, the division was completed in 1948, when the Organization for European Economic Cooperation (OEEC) and the Council for Mutual Economic Cooperation (COMECON) were formed. Austria, Belgium, Denmark, France, Great Britain, Greece, Iceland, Ireland, Italy, Luxembourg, the Netherlands, Norway, Portugal, Sweden, Switzerland and Turkey, together with the American, British and French occupation zones in Germany, which later formed the Federal Republic of Germany, became members of the OEEC. Albania, Bulgaria, Czechoslovakia, Hungary, Poland, Romania and the USSR, together with the Soviet occupation zone in Germany, which later formed the German Democratic Republic, became members of COMECON. Only two European market economies were absent from the OEEC: Spain, because the USA excluded it from the Marshall Plan for political reasons (it was to join the OEEC one decade later), and Finland, because of Soviet diplomatic pressure (it was later to find ways of informal cooperation with the OEEC). Only one centrally

\footnotetext{
*Professor, ISEG Lisbon School of Economics \& Management, Portugal. ${ }^{ \pm}$Professor, ISEG Lisbon School of Economics \& Management, Portugal.
} 
planned economy was absent from COMECON: Yugoslavia, because of its ideological dissension with the USSR (it would become a leader of the so-called non-aligned movement, created in 1955, and tried to develop an original form of market socialism one decade later). From a political point of view, the division was confirmed in 1949, when the formation of the North Atlantic Treaty Organization (NATO) took place, and in 1955, when the formation of the Warsaw Pact Organization took place. Belgium, Canada, Denmark, France, Great Britain, Iceland, Italy, Luxembourg, the Netherlands, Norway, Portugal and the USA were the founding members of NATO (Greece, Turkey and the Federal Republic of Germany were to join later). Membership of the Warsaw Pact Organization coincided at first with membership of COMECON (which was later joined by non-European countries). At the beginning of the 1960s, Albania aligned with the People's Republic of China, when its ideological dissension with the USSR occurred, and left COMECON and the Warsaw Pact Organization for all practical purposes (although not from a formal point of view). Other countries managed to achieve a relative autonomy within their groups (France and Romania are the most evident cases), but the limits of any experiment of this type were clearly illustrated by the outcome of the revolt of Hungary in 1956, the so-called Prague spring of 1968, or the revolutionary process in Portugal between 1974 and 1976.

Countries from the two zones only met in international organizations at the world level, especially the United Nations Organization (UNO), and its specialized agencies. However, countries with centrally planned economies and communist political regimes were absent from the organizations designed to form the framework for the international economic order, namely the International Monetary Fund (IMF), the International Bank for Reconstruction and Development (the core of the World Bank group) and the General Agreement on Tariffs and Trade (GATT), which became the superstructures of the capitalist part of the world economy.

Countries from the two zones created separate specifically European organizations for cooperation in several economic, political and cultural fields. Besides the OEEC/COMECON and the NATO/Warsaw Pact Organization pairs already mentioned, an interesting case in point is the twin organizations created for cooperation in the field of radio and television. As a matter of fact, the development of radio and television broadcasting led quite naturally to international cooperation in the field. In Europe, as was to be expected, this meant two separate international organizations: the European Broadcasting Union (EBU), usually known by the name of its operational service, Eurovision, was created in 1950, with its headquarters in Geneva and brought together broadcasting organizations from European and Mediterranean countries with market economies and democratic or right-wing authoritarian political regimes; the International Radio and Television Organization (IRTO), usually known by the name of its operational service, Intervision, was also created in 1950, with its headquarters in Prague and brought together broadcasting organizations from countries with centrally planned economies and communist political regimes. France, the Federal Republic of Germany, Italy, Luxembourg, Switzerland, and the United Kingdom were the founding members of Eurovision, which was later joined by Austria, Belgium, 
Denmark, Finland, Greece, Iceland, Ireland, Monaco, the Netherlands, Norway, Portugal, Spain, Sweden, Turkey, and Yugoslavia. Bulgaria, Czechoslovakia, the German Democratic Republic, Finland, Hungary, Poland, Romania and the USSR belonged to Intervision. In this particular instance, there was one exception to the general rule: Finland belonged to both organizations. However, it was clear that the Intervision affiliation was purely formal for Finland, from both the technical and the programming point of view. Albania and Yugoslavia were in the opposite situation and remained absent from international television cooperation - in the case of Yugoslavia, this situation continued until it joined Eurovision already in its 1960s market socialism phase.

There was an almost complete absence of specifically pan-European organizations bringing together countries from the two zones. An interesting case in point was the Economic Commission for Europe (ECE), which the UNO tried to implement and which soon became a lethargic organization after the OEEC and COMECON had come into being. Only between 1972 and 1975 was it possible to bring together all European countries (with the exception of Albania) under the same umbrella, at a Conference for Security and Cooperation in Europe in Helsinki, and, in spite of the agreement on the so-called Final Act of the Helsinki Conference, only in 1990, after the collapse of the Soviet sphere of influence, although before the collapse of the Soviet Union itself, was it possible to create the Organization for Security and Cooperation in Europe (OSCE).

In this context, it is truly remarkable that the 1950s should have witnessed the foundation of an organization that brought all the European countries together and thereafter remained successfully active throughout the whole period of the socalled cold war. Of course, it was neither an economic nor a political organization, but an organization linked to one aspect of the cultural field of social life: football. The organization in question was (and is) the Union Européenne de Football/ European Football Association (UEFA) and this paper will discuss the reasons for such a remarkable achievement. A brief survey is made of the constitution, membership and organization of UEFA in Section 2. Section 3 shows how UEFA has been able to organize regular competitions between national and club teams from the whole continent without any significant problems, regardless of the different economic and political systems, since the mid-1950s. Special attention is given to the most prestigious competitions organized under the auspices of UEFA, namely the European Championship, the Champions Cup/Champions League, the Cup Winners' Cup, and the Inter-Cities Fairs Cup/UEFA Cup/Europa League. This did not take place without a number of political problems having to be faced, as Section 4 shows. Some concluding remarks follow.

\section{Constitution, Membership and Organization}

UEFA was founded in Basle on 15 June 1954, as a result of the decision taken in 1953 by the Fédération Internationale de Football/International Football Association (FIFA), founded in 1904, to stimulate the formation of football 
associations at a continental level. The first UEFA Congress took place in Vienna on 2 March 1955.

UEFA originally had thirty one members: the national football associations of Albania, Austria, Belgium, Bulgaria, Czechoslovakia, Denmark, England, Finland, France, the Federal Republic of Germany, the German Democratic Republic, Greece, Hungary, Iceland, Ireland, Northern Ireland, Italy, Luxembourg, the Netherlands, Norway, Poland, Portugal, Romania, Saarland, Scotland, Spain, Sweden, Switzerland, the USSR, Wales and Yugoslavia ${ }^{2}$. The football association of Saarland ceased to be a member in 1957, after the referendum that determined the territory becoming a German state (and not a French department). Until the end of the cold war, there were six additions to the member list: Malta (1960), Cyprus (1962), Turkey (1962), Liechtenstein (1974), San Marino (1988) and the Faroe Islands (1990).

After the end of the cold war, membership activity increased for a while. The German Democratic Republic ceased to be a separate UEFA member when the country was absorbed by the Federal Republic of Germany (1990). The divisions of Czechoslovakia, the USSR and Yugoslavia produced a net increase of fourteen members between 1992 and 1996. The seventeen new members were Armenia, Azerbaijan, Belarus, Bosnia-Herzegovina, the Czech Republic, Croatia, Estonia, Georgia, Latvia, Lithuania, Macedonia, Moldova, Russia, Slovakia, Slovenia, Ukraine and Yugoslavia (later Serbia-Montenegro). Kazakhstan, Kyrgyzstan, Tajikistan, Turkmenistan and Uzbekistan, also emanating from the USSR, became members of the Asian Football Confederation. During the same period, Israel and Andorra were also accepted as members. In the case of Israel, the reason was that it was impossible to link it peacefully to the Asian Football Confederation, to which it belonged geographically. $21^{\text {st }}$ century admissions include Kazakhstan (which preferred to switch from Asia to Europe for football purposes) in 2002, Serbia and Montenegro as a result of the political split between the two countries in 2006, Gibraltar in 2013 (overcoming Spanish resistance), and Kosovo in 2016 (overcoming Serbian resistance), raising the present membership to fifty-five.

Thus, it may be said that no European country was excluded from UEFA, regardless of its economic and political orientation, especially during the period of the cold war. As an unplanned symbol of this fact, the very first match of the first competition organized by UEFA was played between teams from two countries with different economic and political orientations, which did not maintain diplomatic relations ${ }^{3}$.

In spite of the absence of any discrimination in terms of UEFA membership based on a country's economic and political orientation, it is possible to say that the leadership of the organization during the cold war years always belonged to the market economy members. This was clearly expressed in the choices for the siege

\footnotetext{
${ }^{2}$ Notice the separation of the football associations of the various parts of the United Kingdom, which dates back to the time of the institutionalization of the game in the British Isles.

${ }^{3}$ The match between Sporting Lisbon (representing Portugal) and Partizan Belgrade (representing Yugoslavia) for the Champions Cup of the 1955-1956 season was played in Lisbon on 4 September 1955 (ending appropriately in a three-all draw).
} 
of the organization, for the President, Secretary-General and membership of the Executive Committee, and also of venues for the main competitions and matches.

The siege of UEFA was established in Paris between its foundation and 1959. Then it moved to Switzerland, first to Bern, and in 1995 to Nyon (where a House of European Football was inaugurated in 1999).

During the six and a half decades of its existence, UEFA has had nine presidents: Ebbe Schwartz (Denmark, 1954-1962), Gustav Wiederkher (Switzerland, 1962-1972), Sandor Barcs (Hungary, as interim president after Wiederkher's death), Artemio Franchi (Italy, 1973-1983), Jacques George (France, 1983-1990), Lenhart Johanssen (Sweden, 1990-2005), Michel Platini (France, 2006-2015), Angel María Villar (Spain, as interim president after Platini's suspension) and Alexander Čeferin (Slovenia, 2016 to the present). Only almost three decades after the end of the cold war, did the organization have an elected President who came from a country that had had a centrally planned economy and a communist political regime (Barcs' interim office between 1972 and 1973 being clearly an unexpected exception to the rule of prevalence of Western origin).

The rule of prevalence of Western origin also applies to the eight men who have held the position of Secretary-General of the organization: Henri Delaunay (France, 1954-1955), Pierre Delaunay (France, 1956-1959), Hans Bangeter (Switzerland, 1960-1988), Gerhard Eigner (Germany, 1989-2003), Lars-Christer Olsson (Sweden, 2004-2007), David Taylor (Scotland, 2007-2009), Gianni Infantino (Switzerland, 2009-2016) and Theodore Theodoridis (Greece, 2016 to the present).

Two Hungarians (Gustav Sebes 1955-1960, and Sandor Barcs 1962-1978), one Czechoslovakian (Vaclav Jira 1978-1992) and one Soviet (Nikolay Ryashentsev 1982-1994) were Vice-Presidents of UEFA during the cold war years, but they amounted to only $18 \%$ of the 22 people performing that function, and nobody from the countries with centrally planned economies and communist political regimes was ever chosen as Treasurer. Membership of the Executive Committee was also clearly biased against those countries: only 6 out of $39(15 \%)$ of members came from those countries. ${ }^{4}$

\section{Competitions}

As might be expected, UEFA's main activity has been the organization of regular football competitions. When the organization was founded, there were proposals for three different competitions:

\footnotetext{
${ }^{4}$ As a matter of fact, the situation did not change much after the end of the cold war: only two vicepresidents, Grigoriy Surkis (Ukraine) and Sándor Csányi (Hungary), came from countries that had had centrally planned economies and communist political regimes; no treasurer came from those countries; and membership of the Executive Committee rose to only $27 \%$ (12 places out of 45).
} 
a) A national team competition similar to the World Cup already organized by FIFA - This led to the European Championship, first organized in 1958-1960, and at four-year intervals since then.

b) A club team competition between the national champions of member countries - This led to two different competitions: the Champions Cup, first organized in 1955-1956, and thereafter on a yearly basis (since 19911992, this competition has been known as the Champions League); and the Cup Winners' Cup, first organized in 1960-1961, and thereafter on a yearly basis until 1998-1999 (in 1999-2000 this competition was merged with the UEFA Cup).

c) A competition between teams from the main European cities - This led to the Inter-Cities Fairs Cup, first organized between 1955 and 1958, then between 1958 and 1960, with the participants being city teams or club teams representing the cities. From 1960-1961 to 1964-1965, this competition became a yearly competition between club teams acting as representatives of the cities; after that the competition involved the best European teams not participating either in the Champions Cup or in the Cup Winners' Cup, being renamed the UEFA Cup in 1971-1972. It absorbed the Cup Winners' Cup in 1999 and became the Europa League in 2009-2010.

In 1955, UEFA also took over responsibility from FIFA for the organization of a junior national team competition, which had begun in 1948 with only European participants.

The number of UEFA competitions was later greatly increased in several ways:

a) Additional club team competitions - The UEFA Super Cup played between the winners of the Champions Cup and the Cup Winners' Cup, since 1974 (after 2000, the Cup Winners' Cup winner was replaced by the UEFA Cup winner), and the Intertoto Cup, a summer competition started in 1961 outside UEFA jurisdiction, included in the UEFA calendar in 1995, and discontinued since 2008.

b) A wider range of junior national team competitions differentiated by age groups: under-17 since 1980; under-19 since 1974; under-21 since 1992.

c) Women's competitions, namely a women's European Championship for national teams since 1984, the UEFA Women's Cup for club teams since 2001-2002, the European Women's under-18 national team championship since 1997-1998 (which became under-19 in 2001-2002), and the European Women's under-17 national team championship since 2007-2008.

d) (Male) futsal (an indoor five-a-side version of the outdoor eleven-a-side game) competitions, namely the European Futsal Championship for national teams since 1995, and the Futsal Cup for club teams since 2002.

e) (Male) competitions organized together with other continental football associations, namely the Intercontinental Cup, a yearly club team competition between the winner of the Champions Cup and the winner of 
the Copa Libertadores da América started in 1960, which became the FIFA Club World Cup in 2006, and the Meridian Cup, a youth competition organized with the African Football Confederation since 1997.

f) A (male) amateur competition between regional teams, the Regions Cup, which existed between 1965 and 1978, and was resumed in 1996.

g) A (male) junior club team competition, the Youth League, parallel to the Champions League, since 2013.

The (male) European Championship between national teams and the three main cups for club teams - Champions Cup/Champions League, Cup Winners' Cup and Inter-Cities Fairs Cup/UEFA Cup/Europa League - have always featured as the main competitions organized by UEFA and deserve some additional attention.

\section{The European Championship}

Participation in the first European Championship (1958-1960) was far from enthusiastic: only seventeen countries - Austria, Bulgaria, Czechoslovakia, Denmark, France, the German Democratic Republic, Greece, Hungary, Ireland, Norway, Poland, Portugal, Romania, Spain, Turkey, the USSR and Yugoslavia played the qualification matches, leading to a final stage held in France. However, the absences had nothing to do with politics, as all the three political groups of democratic, right-wing authoritarian and communist countries were evenly represented. The absences were simply due to a lack of interest in a new competition that as yet carried no prestige ${ }^{5}$.

Such a situation changed during the 1960s. By the end of the decade, all of UEFA's members were to participate in the competition, held every four years, with a final stage being held in the same year as the Olympic Games took place, and with qualifying matches being played during the previous two years. This scheme and the regularity of the event have remained unchanged until today, with very few absences.

Table 1 summarizes the venues for the final stages and the winners of the European Championships.

${ }^{5}$ It should be remembered that a similar situation had befallen the first FIFA world championship, held in Uruguay in 1930, with only fifteen participants out of forty-seven FIFA members. 
Table 1. Venues for the Final Stages and Winners of the European Championships

\begin{tabular}{|l|c|c|c|}
\hline Years & Number of participants & Venue for the final stages & Winner \\
\hline $1958-1960$ & 17 & France & USSR \\
\hline $1962-1964$ & $29(1$ withdrawal $)$ & Spain & Spain \\
\hline $1966-1968$ & 31 & Italy & Italy \\
\hline $1970-1972$ & 32 & Belgium & F. R. Germany \\
\hline $1974-1976$ & 32 & Yugoslavia & Czechoslovakia \\
\hline $1978-1980$ & 32 & Italy & F. R. Germany \\
\hline $1982-1984$ & 33 & France & France \\
\hline $1986-1988$ & 33 & F. R. Germany & Netherlands \\
\hline $1990-1992$ & 34 & Sweden & Denmark \\
\hline $1994-1996$ & 48 & England & Germany \\
\hline $1998-2000$ & 51 & Belgium/Netherlands & France \\
\hline $2002-2004$ & 51 & Portugal & Greece \\
\hline $2006-2008$ & 52 & Austria/Switzerland & Spain \\
\hline $2010-2012$ & 53 & Poland/Ukraine & Spain \\
\hline $2014-2016$ & 54 & France & Portugal \\
\hline
\end{tabular}

Source: www.uefa.com

The venues for the final stages show a clear asymmetry towards countries with market economies and democratic regimes before the end of the cold war: six times out of eight. The two exceptions were Spain, a market economy but an authoritarian right-wing regime, which was chosen as organizer of the final stage in 1964, and Yugoslavia, which was experimenting with market socialism when it was chosen to organize the final stage in 1976. COMECON/Warsaw Pact countries were never awarded the organization of final stages. ${ }^{6}$

In the same period, COMECON / Warsaw Pact countries performed better in terms of victories: the USSR and Czechoslovakia managed to register their names on the roll of honour at the same level as Spain, Italy, France and the Netherlands, and only below the Federal Republic of Germany (two victories). ${ }^{7}$

\section{The Champions Cup/Champions League}

Sixteen clubs were invited to participate in the first Champions Cup in the 1955-1956 season: they came from Austria, Belgium, Denmark, France, the Federal Republic of Germany, Hungary, Italy, the Netherlands, Poland, Portugal, Saarland, Scotland, Spain, Sweden, Switzerland and Yugoslavia. The competition was organized on a simple knock-out basis, which would remain in force until the 1990-1991 season. From 1956-1957 onwards, the Champions Cup was open to the

\footnotetext{
${ }^{6}$ Only in 2012 two former COMECON / Warsaw Pact countries, Poland and Ukraine, jointly hosted the final stage of the European Championship. The 2020 final stage will be played in several cities around Europe: Amsterdam, Baku, Bilbao, Bucharest, Budapest, Copenhagen, Dublin, Glasgow, London, Munich, Rome and Saint-Petersburg. Four out of twelve are located in former COMECON/ Warsaw Pact countries.

${ }^{7}$ Actually, the performance of Eastern Europe national teams was even worse after the end of the cold war. Denmark, Greece and Portugal (one victory each) joined the list of winners, France and Germany also had one victory each and Spain got two victories.
} 
national champions and the winner of the previous year's Champions Cup (and the runner-up in the national championship whenever the national champion was also the previous season's European champion). It may be said that, by the early 1960s, all the national champions of the different European countries were participating in the competition. ${ }^{8}$

Table 2 presents the list of the cities chosen as the venues for the final matches of the Champions Cup and the respective winners.

Table 2. Venues for Finals and Winners of the Champions Cup/Champions League

\begin{tabular}{|c|c|c|c|}
\hline Year & Number of participants & Venue for final & Winner \\
\hline 1955-1956 & 16 & Paris & Real Madrid \\
\hline 1956-1957 & 22 & Madrid & Real Madrid \\
\hline 1957-1958 & 24 & Brussels & Real Madrid \\
\hline 1958-1959 & 29 (2 withdrawals) & Stuttgart & Real Madrid \\
\hline 1959-1960 & 27 (1 withdrawal) & Glasgow & Real Madrid \\
\hline 1960-1961 & 28 (2 withdrawals) & Berne & SL Benfica (Lisbon) \\
\hline 1961-1962 & 29 (1 withdrawal) & Amsterdam & SL Benfica (Lisbon) \\
\hline $1962-1963$ & 30 & London & AC Milan \\
\hline 1963-1964 & 31 & Vienna & Internazionale (Milan) \\
\hline 1964-1965 & 32 & Milan & Internazionale (Milan) \\
\hline 1965-1966 & 31 & Brussels & Real Madrid \\
\hline 1966-1967 & 34 (1 withdrawal) & Lisbon & Celtic (Glasgow) \\
\hline 1967-1968 & 32 (1 withdrawal) & London & Manchester United \\
\hline 1968-1969 & 32 (3 withdrawals) & Madrid & AC Milan \\
\hline 1969-1970 & 33 & Milan & Feyenoord (Rotterdam) \\
\hline 1970-1971 & 33 & London & Ajax (Amsterdam) \\
\hline 1971-1972 & 33 & Rotterdam & Ajax (Amsterdam) \\
\hline 1972-1973 & 30 & Belgrade & Ajax (Amsterdam) \\
\hline 1973-1974 & 31 & Brussels & Bayern (Munich) \\
\hline 1974-1975 & 30 (1 withdrawal) & Paris & Bayern (Munich) \\
\hline $1975-1976$ & 32 & Glasgow & Bayern (Munich) \\
\hline 1976-1977 & 31 & Rome & Liverpool FC \\
\hline 1977-1978 & 33 & London & Liverpool FC \\
\hline 1978-1979 & 33 & Munich & Nottingham Forest \\
\hline 1979-1980 & 33 & Madrid & Nottingham Forest \\
\hline 1980-1981 & 33 & Paris & Liverpool FC \\
\hline 1981-1982 & 33 & Rotterdam & Aston Villa (Birmingham) \\
\hline
\end{tabular}

\footnotetext{
${ }^{8}$ In 1991-1992, the Champions Cup (after 1992-1993 called the Champions League) underwent several changes in its format and rules for participation: the traditional knock-out scheme was combined with a group stage (in the seasons from 1999-2000 to 2002-2003 two group stages); for a while (from 1994-1995 to 1996-1997) participation was restricted to the champions of countries whose teams had performed best in previous editions of the European club competitions; afterwards the champions of all European countries were again allowed to take part, and participation was further extended to include the highest placed clubs in the national championships of those countries whose teams had performed best in previous editions of the European club competitions. Of course, all of these changes were closely linked to the increase in UEFA's revenue from TV advertising and sponsorship: the aim was to increase the number of matches played by clubs from countries that had a higher per capita income and where football enjoyed greater popularity.
} 


\begin{tabular}{|c|c|c|c|}
\hline Year & Number of participants & Venue for final & Winner \\
\hline $1982-1983$ & 33 & Athens & Hamburg SV \\
\hline 1983-1984 & 31 & Rome & Liverpool FC \\
\hline 1984-1985 & 32 & Brussels & Juventus (Turin) \\
\hline $1985-1986$ & 31 & Seville & Steaua (Bucharest) \\
\hline 1986-1987 & 31 & Vienna & FC Porto \\
\hline $1987-1988$ & 32 (1 withdrawal) & Stuttgart & PSV (Eindhoven) \\
\hline 1988-1989 & 31 & Barcelona & AC Milan \\
\hline $1989-1990$ & 32 & Vienna & AC Milan \\
\hline 1990-1991 & 32 & Bari & Red Star (Belgrade) \\
\hline 1991-1992 & 32 & London & FC Barcelona \\
\hline 1992-1993 & 36 & Munich & Olympique Marseille \\
\hline 1993-1994 & 46 & Athens & AC Milan \\
\hline 1994-1995 & 24 & Vienna & Ajax (Amsterdam) \\
\hline 1995-1996 & 24 & Rome & Juventus (Turin) \\
\hline 1996-1997 & 24 & Munich & Borussia Dortmund \\
\hline 1997-1998 & 53 & Amsterdam & Real Madrid \\
\hline 1998-1999 & 54 & Barcelona & Manchester United \\
\hline $1999-2000$ & 71 & Paris & Real Madrid \\
\hline $2000-2001$ & 72 & Milan & Bayern Munich \\
\hline 2001-2002 & 72 & Glasgow & Real Madrid \\
\hline $2002-2003$ & 72 & Manchester & AC Milan \\
\hline 2003-2004 & 72 & Gelsenkirchen & FC Porto \\
\hline $2004-2005$ & 72 & Istanbul & Liverpool FC \\
\hline $2005-2006$ & 74 & Paris & FC Barcelona \\
\hline $2006-2007$ & 74 & Athens & AC Milan \\
\hline $2007-2008$ & 76 & Moscow & Manchester United \\
\hline $2008-2009$ & 76 & Roma & FC Barcelona \\
\hline $2009-2010$ & 76 & Madrid & Internazionale (Milan) \\
\hline $2010-2011$ & 76 & London & FC Barcelona \\
\hline 2011-2012 & 76 & Munich & Chelsea (London) \\
\hline $2012-2013$ & 76 & London & Bayern Munich \\
\hline 2013-2014 & 76 & Lisbon & Real Madrid \\
\hline $2014-2015$ & 77 & Berlin & FC Barcelona \\
\hline $2015-2016$ & 78 & Milan & Real Madrid \\
\hline $2016-2017$ & 78 & Cardiff & Real Madrid \\
\hline 2017-2018 & 79 & Kiev & Real Madrid \\
\hline $2018-2019$ & 79 & Madrid & Liverpool FC \\
\hline $2019-2020$ & 79 & Istanbul & $?$ \\
\hline
\end{tabular}

Source: www.uefa.com

Once more, a complete asymmetry is to be found in the cities chosen as the venues for the finals: only countries with market economies were chosen. Again, the one possible exception is Belgrade, which hosted the 1973 final at a time when the market socialism process was being followed in Yugoslavia. ${ }^{9}$

${ }^{9}$ Only in 2008 and 2018 did former Warsaw Pact capitals, Moscow and Kiev respectively, host a Champions League final. 
As far as victories go, only the Romanian club Steaua Bucharest in 1986 and the Yugoslavian (nowadays Serbian) club Red Star Belgrade in 1991, from among all the Eastern European competitors, have won this competition. This may be deemed a very poor performance as the following table shows.

Table 3. Summary of Champions Cup/Champions League winners

\begin{tabular}{|c|c|c|c|c|c|}
\hline \multicolumn{2}{|l|}{ Country } & \multicolumn{2}{|l|}{ City } & \multicolumn{2}{|l|}{ Club } \\
\hline \multirow{2}{*}{ Spain } & \multirow{2}{*}{18} & Madrid & 13 & Real Madrid & 13 \\
\hline & & Barcelona & 5 & FC Barcelona & 5 \\
\hline \multirow{5}{*}{ England } & \multirow{5}{*}{13} & Liverpool & 6 & Liverpool FC & 6 \\
\hline & & Manchester & 3 & Manchester United & 3 \\
\hline & & Nottingham & 2 & Nottingham Forest & 2 \\
\hline & & Birmingham & 1 & Aston Villa & 1 \\
\hline & & London & 1 & Chelsea & 1 \\
\hline \multirow{3}{*}{ Italy } & \multirow{3}{*}{12} & \multirow{2}{*}{ Milan } & \multirow{2}{*}{10} & AC Milan & 7 \\
\hline & & & & Inter & 3 \\
\hline & & Turin & 2 & Juventus & 2 \\
\hline \multirow{3}{*}{ F. R. G. / Germany } & \multirow{3}{*}{7} & Munich & 5 & Bayern & 5 \\
\hline & & Hamburg & 1 & Hamburg SV & 1 \\
\hline & & Dortmund & 1 & Borussia Dortmund & 1 \\
\hline \multirow{3}{*}{ Netherlands } & \multirow{3}{*}{6} & Amsterdam & 4 & Ajax & 4 \\
\hline & & Rotterdam & 1 & Feyenoord & 1 \\
\hline & & Eindhoven & 1 & PSV & 1 \\
\hline \multirow{2}{*}{ Portugal } & \multirow{2}{*}{4} & Lisbon & 2 & SL Benfica & 2 \\
\hline & & Porto & 2 & FC Porto & 2 \\
\hline Scotland & 1 & Glasgow & 1 & Celtic & 1 \\
\hline Romania & 1 & Bucharest & 1 & Steaua & 1 \\
\hline Yugoslavia / Serbia & 1 & Belgrade & 1 & Red Star & 1 \\
\hline France & 1 & Marseilles & 1 & Olympique Marseille & 1 \\
\hline
\end{tabular}

Source: computation from Table 2.

\section{The Cup Winners' Cup}

The Cup Winners' Cup was organized from 1960-1961 to 1998-1999 between the winners of the national cups (or the runners up, if the winners were to participate in the Champions Cup). As in the case of the Champions Cup, the previous year's winner was also allowed to participate (unless it was able to participate in the Champions Cup). The competition was always played on a simple knock-out basis.

Table 4 shows the list of the cities where the final was played and the respective winners. 
Table 4. Venues for the Finals and Winners of the Cup Winners' Cup

\begin{tabular}{|c|c|c|c|}
\hline Year & Number of participants & Venue for the final & Winner \\
\hline 1960-1961 & 10 & Glasgow - Florence * & Fiorentina \\
\hline 1961-1962 & 23 & Glasgow - Stuttgart ** & Atlético Madrid \\
\hline $1962-1963$ & 25 (1 withdrawal) & Rotterdam & $\begin{array}{l}\text { Tottenham } \\
\text { (London) }\end{array}$ \\
\hline 1963-1964 & 30 & Brussels - Antwerp $* *$ & $\begin{array}{l}\text { Sporting CP } \\
\text { (Lisbon) }\end{array}$ \\
\hline 1964-1965 & 31 & London & West Ham (London) \\
\hline 1965-1966 & 31 & Glasgow & Borussia Dortmund \\
\hline 1966-1967 & 32 & Nuremberg & Bayern (Munich) \\
\hline 1967-1968 & 32 & Rotterdam & AC Milan \\
\hline 1968-1969 & 30 (3 withdrawals) & Basle & Slovan (Bratislava) \\
\hline 1969-1970 & 33 & Vienna & Manchester City \\
\hline 1970-1971 & 34 & Athens - Athens $* *$ & Chelsea (London) \\
\hline 1971-1972 & 34 & Barcelona & Glasgow Rangers \\
\hline $1972-1973$ & 32 & Salonika & AC Milan \\
\hline 1973-1974 & 32 & Rotterdam & FC Magdeburg \\
\hline 1974-1975 & 32 (1 withdrawal) & Basle & Dynamo Kiev \\
\hline $1975-1976$ & 32 & Brussels & $\begin{array}{l}\text { Anderlecht } \\
\text { (Brussels) }\end{array}$ \\
\hline 1976-1977 & 33 & Amsterdam & Hamburg SV \\
\hline $1977-1978$ & 33 & Paris & $\begin{array}{l}\text { Anderlecht } \\
\text { (Brussels) }\end{array}$ \\
\hline 1978-1979 & 31 & Basle & FC Barcelona \\
\hline $1979-1980$ & 34 (1 withdrawal) & Brussels & Valencia CF \\
\hline 1980-1981 & 34 & Dusseldorf & Dinamo Tbilisi \\
\hline 1981-1982 & 33 & Barcelona & FC Barcelona \\
\hline 1982-1983 & 34 & Gothenburg & Aberdeen FC \\
\hline 1983-1984 & 33 & Basle & Juventus (Turin) \\
\hline 1984-1985 & 32 & Rotterdam & Everton (Liverpool) \\
\hline 1985-1986 & 31 & Lyon & Dynamo Kiev \\
\hline 1986-1987 & 32 & Athens & Ajax (Amsterdam) \\
\hline 1987-1988 & 33 & Strasbourg & KV Mechelen \\
\hline 1988-1989 & 33 & Berne & FC Barcelona \\
\hline 1989-1990 & 33 & Gothenburg & Sampdoria (Genoa) \\
\hline 1990-1991 & 33 & Rotterdam & Manchester United \\
\hline 1991-1992 & 34 & Lisbon & Werder Bremen \\
\hline 1992-1993 & 36 & London & Parma FC \\
\hline 1993-1994 & 43 & Copenhagen & Arsenal (London) \\
\hline 1994-1995 & 44 & Paris & Real Zaragoza \\
\hline 1995-1996 & 48 & Brussels & Paris Saint Germain \\
\hline 1996-1997 & 49 & Rotterdam & FC Barcelona \\
\hline 1997-1998 & 47 & Stockholm & Chelsea (London) \\
\hline 1998-1999 & 49 & Birmingham & Lazio (Rome) \\
\hline
\end{tabular}

Source: www.uefa.com

*This final was played on a two-leg home-and-away basis; ** These finals were replayed after a draw in the first match. 
No final match in this competition was ever played in a non-market economy, nor even in Yugoslavia. However, the competition was won five times by clubs from the COMECON/Warsaw Pact area, namely Slovan Bratislava (1969), FC Magdeburg (1974), Dynamo Kiev (1975 and 1986) and Dinamo Tbilisi (1981). Anyway, once more, this European area shows a rather poor performance, as can be seen in the following table.

Table 5. Summary of the Winners of the Cup Winners' Cup

\begin{tabular}{|c|c|c|c|c|c|}
\hline \multicolumn{2}{|l|}{ Country } & \multicolumn{2}{|c|}{ City } & \multicolumn{2}{|l|}{ Club } \\
\hline \multirow{7}{*}{ England } & \multirow{7}{*}{8} & \multirow{4}{*}{ London } & \multirow{4}{*}{5} & Chelsea & 2 \\
\hline & & & & Tottenham & 1 \\
\hline & & & & West Ham & 1 \\
\hline & & & & Arsenal & 1 \\
\hline & & \multirow{2}{*}{ Manchester } & \multirow{2}{*}{2} & Manchester City & 1 \\
\hline & & & & Manchester United & 1 \\
\hline & & Liverpool & 1 & Everton & 1 \\
\hline \multirow{4}{*}{ Spain } & \multirow{4}{*}{7} & Barcelona & 4 & FC Barcelona & 4 \\
\hline & & Madrid & 1 & Atlético Madrid & 1 \\
\hline & & Valencia & 1 & Valencia CF & 1 \\
\hline & & Zaragoza & 1 & Real Zaragoza & 1 \\
\hline \multirow{6}{*}{ Italy } & \multirow{6}{*}{7} & Milan & 2 & AC Milan & 2 \\
\hline & & Florence & 1 & Fiorentina & 1 \\
\hline & & Turin & 1 & Juventus & 1 \\
\hline & & Genoa & 1 & Sampdoria & 1 \\
\hline & & Parma & 1 & Parma FC & 1 \\
\hline & & Rome & 1 & Lazio & 1 \\
\hline \multirow{4}{*}{ F. R. G./Germany } & \multirow{4}{*}{4} & Dortmund & 1 & Borussia Dortmund & 1 \\
\hline & & Munich & 1 & Bayern & 1 \\
\hline & & Hamburg & 1 & Hamburg SV & 1 \\
\hline & & Bremen & 1 & Werder Bremen & 1 \\
\hline G. D. R./Germany & 1 & Magdeburg & 1 & FC Magdeburg & 1 \\
\hline \multirow{2}{*}{ Belgium } & \multirow{2}{*}{3} & Brussels & 2 & Anderlecht & 2 \\
\hline & & Malines & 1 & KV Mechelen & 1 \\
\hline U. S. S. R./Ukraine & 2 & Kiev & 2 & Dynamo Kiev & 2 \\
\hline U. S. S. R./Georgia & 1 & Tbilisi & 1 & Dinamo Tbilisi & 1 \\
\hline \multirow{2}{*}{ Scotland } & \multirow{2}{*}{2} & Glasgow & 1 & Glasgow Rangers & 1 \\
\hline & & Aberdeen & 1 & Aberdeen FC & 1 \\
\hline Netherlands & 1 & Amsterdam & 1 & Ajax & 1 \\
\hline Portugal & 1 & Lisbon & 1 & Sporting CP & 1 \\
\hline $\begin{array}{l}\text { Czechoslovakia/ } \\
\text { Slovakia }\end{array}$ & 1 & Bratislava & 1 & Slovan & 1 \\
\hline France & 1 & Paris & 1 & Paris Saint-Germain & 1 \\
\hline
\end{tabular}

Source: Computation from Table 4.

\section{The Inter-Cities Fairs Cup/UEFA Cup/Europe League}

As explained above, the first edition of the Inter-Cities Fairs Cup was played between 1955 and 1958, and the second edition between 1958 and 1960, with either city teams or club teams representing the cities as participants. The first edition combined both a group stage and a knock-out stage, but the second one adopted a pure knock-out format, which remained in force until 2003-2004. Since 
1960-1961, this competition (after 1971-1972 called the UEFA Cup) has been a yearly competition between club teams. In the early 1960s, clubs still participated as representatives of cities, but since 1964-1965 the teams involved have been the highest placed clubs in the national championships of the previous year not participating in either the Champions Cup or the Cup Winners' Cup. The previous year's winner was also allowed to participate, as was the case in the other European club competitions (unless it was able to participate in either of the other European club competitions). ${ }^{10}$

Table 6 shows the list of the cities where the final was played and the respective winners.

Table 6. Venues for the Finals and Winners of the Inter-Cities Fairs Cup/UEFA Cup/Europe League

\begin{tabular}{|c|c|c|c|}
\hline Years & $\begin{array}{l}\text { Number of } \\
\text { participants }\end{array}$ & Venue for final & Winner \\
\hline $1955-1958$ & 12 (2 withdrawals) & London - Barcelona $*$ & FC Barcelona \\
\hline $1958-1960$ & 16 & Birmingham - Barcelona * & FC Barcelona \\
\hline $1960-1961$ & 16 & Birmingham - Rome $*$ & AS Roma \\
\hline 1961-1962 & 28 & Valencia - Barcelona * & Valencia CF \\
\hline 1962-1963 & 32 & Zagreb - Valencia $*$ & Valencia CF \\
\hline 1963-1964 & 32 & Barcelona & Real Zaragoza \\
\hline 1964-1965 & 48 & Turin & $\begin{array}{c}\text { Ferencvaros } \\
\text { (Budapest) }\end{array}$ \\
\hline 1965-1966 & 48 & Barcelona -Zaragoza * & FC Barcelona \\
\hline 1966-1967 & 48 & Zagreb - Leeds $*$ & Dinamo Zagreb \\
\hline 1967-1968 & 48 & Leeds - Budapest * & Leeds United \\
\hline $1968-1969$ & 64 (2 withdrawals) & Newcastle - Budapest * & Newcastle United \\
\hline $1969-1970$ & 64 & Brussels - London $*$ & Arsenal (London) \\
\hline 1970-1971 & 64 & Turin - Leeds $*$ & Leeds United \\
\hline 1971-1972 & 64 (2 withdrawals) & Wolverhampton - London * & Tottenham (London) \\
\hline 1972-1973 & 64 (1 withdrawal) & $\begin{array}{c}\text { Liverpool - } \\
\text { Mönchengladbach * }\end{array}$ & Liverpool FC \\
\hline 1973-1974 & 64 & London - Rotterdam * & $\begin{array}{l}\text { Feyenoord } \\
\text { (Rotterdam) }\end{array}$ \\
\hline $1974-1975$ & 64 (1 withdrawal) & Düsseldorf - Enschede * & $\begin{array}{c}\text { Borussia } \\
\text { Mönchengladbach }\end{array}$ \\
\hline $1975-1976$ & 64 & Liverpool - Brugge * & Liverpool FC \\
\hline 1976-1977 & 64 & Turin - Bilbao * & Juventus (Turin) \\
\hline $1977-1978$ & 64 & Bastia - Eindhoven * & PSV (Eindhoven) \\
\hline 1978-1979 & 64 & Belgrade - Düsseldorf $*$ & $\begin{array}{c}\text { Borussia } \\
\text { Mönchengladbach }\end{array}$ \\
\hline $1979-1980$ & 64 & $\begin{array}{l}\text { Mönchengladbach - } \\
\text { Frankfurt * }\end{array}$ & Eintracht (Frankfurt) \\
\hline
\end{tabular}

\footnotetext{
${ }^{10}$ Since 1999-2000, the winners of national cups have also participated in the UEFA Cup, which has also started to receive some of the clubs eliminated from the Champions League. Since the 20042005 season, the UEFA Cup has included a group stage combined with several knock-out stages. From 2009-2010 on, it was renamed Europa League.
} 


\begin{tabular}{|c|c|c|c|}
\hline Years & $\begin{array}{l}\text { Number of } \\
\text { participants }\end{array}$ & Venue for final & Winner \\
\hline 1980-1981 & 64 & Ipswich - Amsterdam * & Ipswich Town \\
\hline 1981-1982 & 64 & Gothenburg - Hamburg * & IFK (Gothenburg) \\
\hline 1982-1983 & 64 & Brussels - Lisbon * & $\begin{array}{c}\text { Anderlecht } \\
\text { (Brussels) }\end{array}$ \\
\hline 1983-1984 & 64 & Brussels - London $*$ & Tottenham (London) \\
\hline 1984-1985 & 64 & Szekesfehervar-Madrid * & Real Madrid \\
\hline $1985-1986$ & 64 & Madrid - Berlin $*$ & Real Madrid \\
\hline 1986-1987 & 64 & Gothenburg - Dundee $*$ & IFK (Gothenburg) \\
\hline 1987-1988 & 64 & Barcelona-Leverkussen * & Bayer Leverkussen \\
\hline 1988-1989 & 64 & Naples - Stuttgart * & SSC Napoli \\
\hline $1989-1990$ & 65 & Turin - Avellino $*$ & Juventus (Turin) \\
\hline 1990-1991 & 64 & Milan - Rome * & Inter (Milan) \\
\hline 1991-1992 & 64 & Turin - Amsterdam * & Ajax (Amsterdam) \\
\hline 1992-1993 & 64 & Dortmund - Turin * & Juventus (Turin) \\
\hline 1993-1994 & 64 & Vienna - Milan * & Inter (Milan) \\
\hline 1994-1995 & 91 & Parma-Milan * & Parma FC \\
\hline 1995-1996 & 98 & Munich - Bordeaux * & Bayern (Munich) \\
\hline 1996-1997 & 102 & Gelsenkirchen - Milan * & $\begin{array}{c}\text { Schalke 04 } \\
\text { (Gelsenkirchen) }\end{array}$ \\
\hline 1997-1998 & 102 & Paris & Inter (Milan) \\
\hline 1998-1999 & 102 & Moscow & Parma FC \\
\hline 1999-2000 & 90 & Copenhagen & $\begin{array}{c}\text { Galatasaray } \\
\text { (Istanbul) }\end{array}$ \\
\hline $2000-2001$ & 93 & Dortmund & Liverpool FC \\
\hline 2001-2002 & 93 & Rotterdam & $\begin{array}{c}\text { Feyenoord } \\
\text { (Rotterdam) }\end{array}$ \\
\hline $2002-2003$ & 93 & Seville & FC Porto \\
\hline 2003-2004 & 92 & Gothenburg & Valencia CF \\
\hline 2004-2005 & 125 & Lisbon & CSKA Moscow \\
\hline $2005-2006$ & 124 & Eindhoven & Sevilla FC \\
\hline $2006-2007$ & 123 & Glasgow & Sevilla FC \\
\hline $2007-2008$ & 137 & Manchester & $\begin{array}{l}\text { Zenit (Saint } \\
\text { Petersburg) } \\
\end{array}$ \\
\hline 2008-2009 & 195 & Istanbul & Shakthar Donetzk \\
\hline $2009-2010$ & 192 & Hamburg & Atlético Madrid \\
\hline 2010-2011 & 194 & Dublin & FC Porto \\
\hline 2011-2012 & 194 & Bucharest & Atlético Madrid \\
\hline 2012-2013 & 193 & Amsterdam & Chelsea \\
\hline 2013-2014 & 194 & Turin & Sevilla FC \\
\hline 2014-2015 & 195 & Warsaw & Sevilla FC \\
\hline $2015-2016$ & 192 & Basel & Sevilla FC \\
\hline 2016-2017 & 192 & Stockholm & Manchester United \\
\hline 2017-2018 & 190 & Lyon & Atlético Madrid \\
\hline 2018-2019 & 213 & Baku & Chelsea (London) \\
\hline $2019-2020$ & 213 & Gdansk & ? \\
\hline
\end{tabular}

Source: www.uefa.com.

*These finals were played on a two-leg home-and-away basis. 
Only after the end of the cold war, were cities in Eastern Europe chosen to organize the final match of the UEFA Cup/Europe League. ${ }^{11}$ Note that as, until 1997-1998, the finals were mostly played on a two-leg home-and-away basis, several of these final matches were played in Eastern Europe: in the Yugoslavian (now Croatian) city of Zagreb in 1963 and 1967, in the Hungarian cities of Budapest in 1968 and 1969 and Szekesfehervar in 1985, and in the Yugoslavian (now Serbian) city of Belgrade in 1979.

Table 7. Summary of the Winners of the Inter-Cities Fairs Cup/UEFA Cup

\begin{tabular}{|c|c|c|c|c|c|}
\hline \multicolumn{2}{|l|}{ Country } & \multicolumn{2}{|l|}{ City } & \multicolumn{2}{|l|}{ Club } \\
\hline \multirow{6}{*}{ Spain } & \multirow{6}{*}{17} & Seville & 5 & Sevilla FC & 5 \\
\hline & & Madrid & 5 & Atlético Madrid & 3 \\
\hline & & & & Real Madrid & 2 \\
\hline & & Barcelona & 3 & FC Barcelona & 3 \\
\hline & & Valencia & 3 & Valencia CF & 3 \\
\hline & & Zaragoza & 1 & Real Zaragoza & 1 \\
\hline \multirow{8}{*}{ England } & \multirow{8}{*}{13} & \multirow{3}{*}{ London } & \multirow[t]{3}{*}{5} & Tottenham & 2 \\
\hline & & & & Chelsea & 2 \\
\hline & & & & Arsenal & 1 \\
\hline & & Liverpool & 3 & Liverpool FC & 3 \\
\hline & & Leeds & 2 & Leeds United & 2 \\
\hline & & Newcastle & 1 & Newcastle United & 1 \\
\hline & & Ipswich & 1 & Ipswich Town & 1 \\
\hline & & Manchester & 1 & Manchester United & 1 \\
\hline \multirow{5}{*}{ Italy } & \multirow{5}{*}{10} & Turin & 3 & Juventus & 3 \\
\hline & & Milan & 3 & Inter & 3 \\
\hline & & Parma & 2 & Parma FC & 2 \\
\hline & & Rome & 1 & AS Roma & 1 \\
\hline & & Naples & 1 & SSC Napoli & 1 \\
\hline \multirow{5}{*}{ Germany } & \multirow{5}{*}{6} & Mönchengladbach & 2 & Borussia Mönchengladbach & 2 \\
\hline & & Frankfurt & 1 & Eintracht & 1 \\
\hline & & Leverkussen & 1 & Bayer Leverkussen & 1 \\
\hline & & Munich & 1 & Bayern & 1 \\
\hline & & Gelsenkirchen & 1 & Schalke 04 & 1 \\
\hline \multirow{3}{*}{ Netherlands } & \multirow{3}{*}{4} & Rotterdam & 2 & Feyenoord & 2 \\
\hline & & Eindhoven & 1 & PSV & 1 \\
\hline & & Amsterdam & 1 & Ajax & 1 \\
\hline Portugal & 2 & Porto & 2 & FC Porto & 2 \\
\hline Sweden & 2 & Gothenburg & 2 & IFK & 2 \\
\hline \multirow{2}{*}{ Russia } & \multirow{2}{*}{2} & Moscow & 1 & CSKA Moscow & 1 \\
\hline & & Saint Petersburg & 1 & Zenit & 1 \\
\hline Belgium & 1 & Brussels & 1 & Anderlecht & 1 \\
\hline Hungary & 1 & Budapest & 1 & Ferencvaros & 1 \\
\hline Yugoslavia/Croatia & 1 & Zagreb & 1 & Dinamo Zagreb & 1 \\
\hline Turkey & 1 & Istanbul & 1 & Galatasaray & 1 \\
\hline Ukraine & 1 & Donetsk & 1 & Shaktar & 1 \\
\hline
\end{tabular}

Source: Computation from Table 6.

\footnotetext{
${ }^{11}$ Namely Moscow in 1999, Bucharest in 2012, Warsaw in 2015 and Gdansk in 2020.
} 
Once more, clubs from Eastern Europe seldom appear in the winners' list, as table above shows: Ferencvaros from Budapest in 1965 and Dinamo Zagreb in 1967 were the only exceptions during the cold war period. ${ }^{12}$

\section{Political Problems}

Although political problems never paralysed the functioning of UEFA and the organization of its competitions, this does not mean that such problems did not exist. They may be classified under three main types: visa problems, boycotts and exclusions.

As UEFA (2004) acknowledges "[...] visa problems arose for delegations, $[\ldots]$, teams and media representatives, [...], not to mention spectators". The most significant visa problem was the refusal by Spanish authorities to issue visas to allow the Spanish and Soviet national teams to play the quarter-finals of the first European Championship. This led to the exclusion of Spain from the final stage of the 1958-1960 European Championship. However, Spain was assigned the organization of the next final stage in 1964, in which the USSR national team was one of the participants, proving that the previous diplomatic difficulties had been overcome.

Boycotts were attempted twice by COMECON/Warsaw Pact countries. In 1961, the German Democratic Republic withdrew from the International Youth Tournament to be held in Portugal, and Hungary and Yugoslavia followed suit out of solidarity. In the following season, the Portuguese authorities retaliated by refusing to grant visas making it possible for the Motor Jena team from the German Democratic Republic to come to Portugal to play the quarter-finals of the Cup Winners Cup. As a consequence, the Portuguese representative, Leixões, was forced to play both the home and away fixtures in the German Democratic Republic (with unfavourable results). The retaliation character of the decision was clear, because in the previous knock-out stage Progresul Bucharest from Romania, a communist country that had participated in the 1961 International Youth Tournament in Portugal, had been given visas to play in Portugal. In 1968, following the crisis triggered by the invasion of Czechoslovakia by Warsaw Pact countries, teams from the USSR, Bulgaria, Hungary, and the German Democratic Republic pulled out of UEFA club competitions. In both cases, the boycott petered out.

To sum up: UEFA never gave in to pressures to take political decisions against its members during the cold war years. Such a strategy paid off, as visa refusals to teams and boycotts remained few in number and quite limited in time. It was after the end of the cold war that the only exclusion for political reasons was to occur: as a consequence of the United Nations sanctions against Yugoslavia, the country was forbidden to play the final stage of the 1992 European Championship for

\footnotetext{
${ }^{12}$ After the end of the cold war CSKA Moscow, Zenit Saint Petersburg and Shaktar Donetsk also joined the list.
} 
which it had qualified ${ }^{13}$. This isolated breach in the political neutrality of UEFA was again short-lived and had no long-term consequences. ${ }^{14}$

\section{Concluding Remarks}

UEFA's success as the only pan-European organization to thrive during the cold war years may be explained by two reasons: the popularity of football, and UEFA's political neutrality. As for the sport's popularity, it is significant that television programme exchanges between the two rival international radio and television broadcasting organizations, Eurovision and Intervision, during the cold war years consisted mainly of broadcasts of football matches. As for political neutrality, the attitude towards the political problems mentioned in Section 4 was quite clear.

Moreover, the importance of football grew with the increase in disposable income and leisure time, which happened all over Europe, albeit at different rates in different countries. Thus, football gradually became a key common element in European culture. Poor representation on UEFA's highest bodies, an almost complete absence from major events, and even a fairly unsuccessful participation in UEFA's competitions could not deter COMECON/Warsaw Pact countries from participating in such a popular endeavour.

\section{References}

\section{Written Sources}

UEFA. 2004. UEFA 50 years 1954-2004. UEFA, Nyon. Vieli, A. 2014. UEFA 60 ans au Cour du Football. UEFA, Nyon. Sports press

\section{Websites}

FIFA: www.fifa.org

UEFA: www.uefa.com

EUROVISION: http:// www.eurovision.tv/content/view/213/187/

INTERVISION: http://www.transdiffusion.org/intertel/gallery/intervision/

National football associations (see appendix).

\footnotetext{
${ }^{13}$ Curiously, Denmark, called in to replace Yugoslavia, then became European champions.

${ }^{14}$ Other exclusions occurred, both during the cold war period and more recently, but they were the consequence of bad behaviour of fans. The most important case was the exclusion of English teams for five years after the incidents at the final of the Champions Cup of 1985 in Brussels that led to the death of 39 people. Moreover, political clashes have led to decisions to avoid matches between some pairs of countries as much as possible. Active restrictions of this type today include Armenia/ Azerbaijan, Gibraltar/Spain, Kosovo/Bosnia and Herzegovina, Kosovo/Serbia and Russia/Ukraine matches.
} 


\section{Appendix. UEFA Members}

Name of national football association and date of foundation according to the national football association website when available, or according to the FIFA website otherwise. Date of FIFA affiliation according to the FIFA website. Date of UEFA affiliation according to the UEFA website.

\begin{tabular}{|c|c|c|c|c|c|}
\hline Country & $\begin{array}{c}\text { National football } \\
\text { association }\end{array}$ & Foundation & $\begin{array}{c}\text { FIFA } \\
\text { affiliation }\end{array}$ & $\begin{array}{c}\text { UEFA } \\
\text { affiliation }\end{array}$ & Website \\
\hline Albania & $\begin{array}{l}\text { Federata Shqiptare e } \\
\text { Futbollit }\end{array}$ & 1930 & 1932 & 1954 & www.fshf.org \\
\hline Andorra & $\begin{array}{c}\text { Federació Andorrana } \\
\text { de Futbol }\end{array}$ & 1994 & 1996 & 1996 & www.faf.ad \\
\hline Armenia & $\begin{array}{c}\text { Football Federation } \\
\text { of Armenia }\end{array}$ & 1992 & 1992 & 1992 & www.ffa.am \\
\hline Austria & $\begin{array}{c}\text { Österreichischer } \\
\text { Fussball-Bund }\end{array}$ & 1904 & 1905 & 1954 & www.oefb.at \\
\hline Azerbaijan & $\begin{array}{c}\text { Azärbaycan Futbol } \\
\text { Federasiyalari } \\
\text { Assosiasiyasi }\end{array}$ & 1992 & 1994 & 1994 & www.affa.az \\
\hline Belarus (a) & $\begin{array}{c}\text { Belaruckia } \\
\text { Federatsia Futbola } \\
\end{array}$ & 1989 & 1992 & 1993 & www.bff.by \\
\hline Belgium & $\begin{array}{l}\text { Union Royale Belge } \\
\text { des Sociétés de } \\
\text { Football-Association }\end{array}$ & 1895 & 1904 & 1954 & www.footbel.com \\
\hline $\begin{array}{c}\text { Bosnia- } \\
\text { Herzegovina }\end{array}$ & $\begin{array}{c}\text { Nogometni } \\
\text { Fudbalski Savez } \\
\text { Bosne i Herzegovine }\end{array}$ & 1992 & 1996 & 1998 & www.nfsbih.ba \\
\hline Bulgaria & $\begin{array}{c}\text { Bulgarski Futbolen } \\
\text { Suyuz }\end{array}$ & 1923 & 1924 & 1954 & www.bfunion.bg \\
\hline Croatia (b) & $\begin{array}{l}\text { Hrvatski Nogometni } \\
\text { Savez }\end{array}$ & 1912 & 1992 & 1993 & www.hns-cff.hr \\
\hline Cyprus & $\begin{array}{c}\text { Kupriaké } \\
\text { Omospondia } \\
\text { Podosfairou } \\
\end{array}$ & 1934 & 1948 & 1962 & www.cfa.com.cy \\
\hline $\begin{array}{c}\text { Czech } \\
\text { Republic (c) }\end{array}$ & $\begin{array}{l}\text { Ceskomoravsky } \\
\text { Fotbalovy Svaz } \\
\end{array}$ & 1901 & 1907 & 1954 & www.fotbal.cz \\
\hline Denmark & Dansk Boldspil-Union & 1889 & 1904 & 1954 & www.dbu.dk \\
\hline England & Football Association & 1863 & 1905 & 1954 & www.thefa.com \\
\hline Estonia (d) & Eesti Jalgpalli Liit & 1921 & 1923 & 1992 & www.jalgpall.ee \\
\hline Faroe Islands & $\begin{array}{c}\text { Fótbóltssamband } \\
\text { Føroya } \\
\end{array}$ & 1979 & 1988 & 1990 & www.football.fo \\
\hline Finland & Suomen Palloliitto & 1907 & 1908 & 1954 & www.palloliitto.fi \\
\hline France (e) & $\begin{array}{c}\text { Fédération Française } \\
\text { de Football }\end{array}$ & 1919 & 1904 & 1954 & www.fff.fr \\
\hline Georgia & $\begin{array}{l}\text { Georgian Football } \\
\text { Association }\end{array}$ & 1990 & 1992 & 1992 & www.gff.ge \\
\hline Germany (f) & $\begin{array}{l}\text { Deutscher Fussball- } \\
\text { Bund }\end{array}$ & 1900 & 1904 & 1954 & www.dfb.de \\
\hline Gibraltar & $\begin{array}{c}\text { Gibraltar Football } \\
\text { Association }\end{array}$ & 1895 & 2016 & 2013 & www.gibraltarfa.com \\
\hline Greece & $\begin{array}{c}\text { Ellenike } \\
\text { Podosfairike } \\
\text { Omospondia } \\
\end{array}$ & 1926 & 1927 & 1954 & www.epo.gr \\
\hline Hungary & $\begin{array}{l}\text { Magyari Labdarúgó } \\
\text { Szövetség }\end{array}$ & 1901 & 1906 & 1954 & www.mlsz.hu \\
\hline Iceland & $\begin{array}{l}\text { Knattspyrnusamband } \\
\text { Islands }\end{array}$ & 1947 & 1947 & 1954 & www.ksl.is \\
\hline
\end{tabular}




\begin{tabular}{|c|c|c|c|c|c|}
\hline Country & $\begin{array}{c}\begin{array}{c}\text { National football } \\
\text { association }\end{array} \\
\end{array}$ & Foundation & $\begin{array}{c}\text { FIFA } \\
\text { affiliation }\end{array}$ & $\begin{array}{c}\text { UEFA } \\
\text { affiliation }\end{array}$ & Website \\
\hline Ireland & $\begin{array}{c}\text { Football Association } \\
\text { of Ireland }\end{array}$ & 1921 & 1923 & 1954 & www.fai.ie \\
\hline Israel (g) & $\begin{array}{c}\text { Israel Football } \\
\text { Association }\end{array}$ & 1928 & 1929 & 1994 & $\begin{array}{l}\text { www.Israel- } \\
\text { football.org.Il }\end{array}$ \\
\hline Italy & $\begin{array}{c}\text { Federazione Italiana } \\
\text { Giuoco Calcio }\end{array}$ & 1898 & 1905 & 1954 & www.figc.it \\
\hline $\begin{array}{c}\text { Kazakhstan } \\
\text { (h) }\end{array}$ & $\begin{array}{c}\text { Kazakstannyn } \\
\text { Futbol Federatchisy }\end{array}$ & 1914 & 1994 & 2002 & www.fsk.kz \\
\hline Kosovo (i) & $\begin{array}{c}\text { Federata e Futbollit } \\
\text { e Kosovës }\end{array}$ & 1946 & 2016 & 2016 & www.fkk.kosova.com \\
\hline Latvia (j) & $\begin{array}{c}\text { Latvijas Futbolas } \\
\text { Federacija }\end{array}$ & 1921 & 1922 & 1992 & www.lff.lv \\
\hline Liechtenstein & $\begin{array}{l}\text { Liechtensteiner } \\
\text { Fussballverband }\end{array}$ & 1934 & 1974 & 1974 & www.lfv.li \\
\hline Lithuania (k) & $\begin{array}{l}\text { Lietuvos futbolo } \\
\text { federacijos }\end{array}$ & 1922 & 1923 & 1992 & www.1ff.lt \\
\hline Luxembourg & $\begin{array}{c}\text { Fédération } \\
\text { Luxembourgeoise de } \\
\text { Football }\end{array}$ & 1908 & 1910 & 1954 & www.football.lu \\
\hline $\begin{array}{l}\text { Macedonia } \\
\text { (1) }\end{array}$ & $\begin{array}{c}\text { Fudbalska } \\
\text { Federatsija na } \\
\text { Makedonia }\end{array}$ & 1948 & 1994 & 1994 & www.ffm.com.mk \\
\hline Malta & $\begin{array}{l}\text { Malta Football } \\
\text { Association }\end{array}$ & 1900 & 1959 & 1960 & www.mfa.com.mt \\
\hline Moldova & $\begin{array}{c}\text { Federatia } \\
\text { Moldoveneasca de } \\
\text { Fotbal }\end{array}$ & 1990 & 1994 & 1993 & www.fmf.md \\
\hline $\begin{array}{l}\text { Montenegro } \\
(\mathrm{m})\end{array}$ & $\begin{array}{c}\text { Fudbalski Savez } \\
\text { Crne Gore }\end{array}$ & 1931 & 2007 & 2007 & www.fscg.co.me \\
\hline Netherlands & $\begin{array}{c}\text { Koninklije } \\
\text { Nederlandse } \\
\text { Voetbalbond }\end{array}$ & 1889 & 1904 & 1954 & www.knvb.nl \\
\hline $\begin{array}{l}\text { Northern } \\
\text { Ireland (n) }\end{array}$ & $\begin{array}{l}\text { Irish Football } \\
\text { Association }\end{array}$ & 1880 & 1911 & 1954 & www.irishfa.com \\
\hline Norway & $\begin{array}{c}\text { Norges } \\
\text { Fotballforbund }\end{array}$ & 1902 & 1908 & 1954 & www.fotball.no \\
\hline Poland & $\begin{array}{c}\text { Polski Zviazek Pilki } \\
\text { Noznei }\end{array}$ & 1919 & 1923 & 1954 & www.pzpn.pl \\
\hline Portugal & $\begin{array}{c}\text { Federação } \\
\text { Portuguesa de } \\
\text { Futebol }\end{array}$ & 1914 & 1923 & 1954 & www.fpf.pt \\
\hline Romania & $\begin{array}{c}\text { Federatia Romana de } \\
\text { Fotbal }\end{array}$ & 1909 & 1923 & 1954 & www.frf.ro \\
\hline Russia (o) & $\begin{array}{c}\text { Rossiickii } \\
\text { Futbolunuii Soyuz }\end{array}$ & 1912 & 1912 & 1954 & www.rsf.ru \\
\hline San Marino & $\begin{array}{c}\text { Federazione } \\
\text { Sammarinese } \\
\text { Giuoco Calcio }\end{array}$ & 1931 & 1988 & 1988 & www.fsgc.sm \\
\hline Scotland & $\begin{array}{c}\text { Scottish Football } \\
\text { Association }\end{array}$ & 1873 & 1910 & 1954 & www.scottishfa.co.uk \\
\hline Serbia (p) & $\begin{array}{c}\text { Fudbalsky Savez } \\
\text { Srbije }\end{array}$ & 1919 & 1921 & 1954 & www.fss.org.rs \\
\hline Slovakia (q) & $\begin{array}{l}\text { Slovensky futbalovy } \\
\text { zväz }\end{array}$ & 1938 & 1994 & 1993 & www.futbalsfz.sk \\
\hline Slovenia (r) & $\begin{array}{c}\text { Nogometna Zvena } \\
\text { Slovenije } \\
\end{array}$ & 1920 & 1994 & 1994 & www.nzs.si \\
\hline Spain & $\begin{array}{c}\text { Real Federación } \\
\text { Española de Futbol }\end{array}$ & 1909 & 1913 & 1954 & www.rfef.es \\
\hline
\end{tabular}




\begin{tabular}{|c|c|c|c|c|c|}
\hline Country & $\begin{array}{c}\text { National football } \\
\text { association }\end{array}$ & Foundation & $\begin{array}{c}\text { FIFA } \\
\text { affiliation }\end{array}$ & $\begin{array}{c}\text { UEFA } \\
\text { affiliation }\end{array}$ & Website \\
\hline Sweden & $\begin{array}{c}\text { Svenska } \\
\text { Fotbollförbundet }\end{array}$ & 1904 & 1904 & 1954 & www.svenskfotboll.se \\
\hline Switzerland & $\begin{array}{c}\text { Schwizerischer } \\
\text { Fussballverband }\end{array}$ & 1895 & 1904 & 1954 & www.football.ch \\
\hline Turkey & $\begin{array}{c}\text { Türkiye Futbol } \\
\text { Federasyonu }\end{array}$ & 1923 & 1923 & 1962 & www.tff.org \\
\hline Ukraine & $\begin{array}{c}\text { Federatsia Futbolu } \\
\text { Ukraïna }\end{array}$ & 1991 & 1992 & 1992 & www.ffu.org.ua \\
\hline Wales & $\begin{array}{c}\text { Football Association } \\
\text { of Wales }\end{array}$ & 1876 & 1910 & 1954 & www.faw.org.uk \\
\hline
\end{tabular}

Notes: (a) The Belarus football association was founded in 1989, when the country was part of the USSR. It became a separate national association after 1991, when the country became fully independent.

(b) The Croatian football association was founded in 1912, when the country was part of AustriaHungary. It became a separate national association between 1941 and 1945 and again after 1991, when the country became fully independent. Between 1919 and 1941 and between 1945 and 1991, the country was part of Yugoslavia. Between 1941 and 1945, the Croatian football association was a member of FIFA.

(c) The Czech football association was founded in 1901, when the country was part of AustriaHungary, but it still obtained FIFA affiliation in spite of this. In 1919, it was transformed into the Czechoslovakian football association, when the country became fully independent and united with Slovakia. Between 1938 and 1945, a separate Slovak football association was created, as a CzechSlovak Federation was established in 1938 and Slovakia seceded from that Federation in 1939. Between 1945 and 1993, Czechoslovakia was united once more, and the Czech football association became the Czechoslovakian football association again. A new separation of Czech and Slovak Republics occurred in 1993 and distinct Czech and Slovak football associations were re-established in that year.

(d) Between 1940 and 1991, there was no separate national Estonian football association, because the country was part of the USSR.

(e) France was represented in the foundation of FIFA by the Union des Sociétés Françaises de Sports Athlétiques. The first French football association was founded in 1906. This association split later, and only in 1919 was a single association reformed again.

(f) When UEFA was founded, there were two German states, the Federal Republic of Germany and the German Democratic Republic, and the territory of Saarland was still awaiting its definitive status. Thus, three German football associations became founding members of UEFA in 1954. The affiliation of the Saarland football association lapsed when the territory became a state of the Federal Republic of Germany in 1957. The affiliation of the German Democratic Republic football association lapsed when the country was absorbed by the Federal Republic of Germany in 1990.

(g) The foundation of the Israel football association occurred in 1928 when the country was part of Palestine, a British mandate of the League of Nations. The state of Israel was proclaimed in 1948.

(h) The Kazakhstan football association was founded in 1914, when the country was part of the Russian Empire. It became a separate national association after 1991, when the country became fully independent. Between 1914 and 1924, the country was part of Russia, and between 1924 and 1991 the country was part of the USSR.

(i) The Kosovo football association was founded in 1946, when the country was part of Yugoslavia. It became a separate national association after 2008, when the country proclaimed its independence, which has not yet (2019) been recognised by the former sovereign power, Serbia.

(j) Between 1940 and 1991, there was no separate national Latvian football association, because the country was part of the USSR.

(k) Between 1940 and 1991, there was no separate national Lithuanian football association, because the country was part of the USSR.

(l) The Macedonian football association was founded in 1948, when the country was part of Yugoslavia. It became a separate national association after 1991, when the country became fully independent. 
(m) The Montenegrin football association was founded in 1931, when the country was part of Yugoslavia. It became a separate national association after 2007, when the country became fully independent. Until 1991, the country was part of Yugoslavia, and between 1991 and 2006 the country was part of the Serbia-Montenegro Federation (officially called Yugoslavia until 2003).

(n) The Irish football association was founded in 1880 and was transformed in 1921 into the Northern Ireland football association. At the same time, a separate football association for the new Republic of Ireland was founded.

(o) Between 1924 and 1991, the Russian football association was transformed into the USSR football association. The USSR included the present-day states of Armenia, Azerbaijan, Belarus, Georgia, Kazakhstan, Moldova, Russia and Ukraine, whose football associations are members of UEFA, and Kyrgyzstan, Tajikistan, Turkmenistan and Uzbekistan, whose football associations are not members of UEFA. After 1940, it also included the present-day states of Estonia, Latvia, and Lithuania, whose football associations are members of UEFA.

(p) The dates indicated refer to the Yugoslavian football association. Yugoslavia included the present-day states of Bosnia-Herzegovina, Croatia, Macedonia, Montenegro, Serbia and Slovenia (and Kosovo, not recognised by Serbia). Its football association became the Serbia-Montenegro football association (until 2003 officially called the Yugoslavian football association) after the other parts of Yugoslavia had seceded. In 2006, it became the Serbian football association, when Montenegro also seceded.

(q) Between 1945 and 1993, there was no Slovak football association, because the country was part of Czechoslovakia.

(r) The Slovenian football association was founded in 1920, when the country was part of Yugoslavia. It became a separate national association after 1991, when the country became fully independent. Between 1920 and 1941 and between 1945 and 1991, the country was part of Yugoslavia; between 1941 and 1945, the country was part of Croatia. 